\title{
Asset Management
}


Downloaded by [] on [26/04/23]. Copyright @ ICE Publishing, all rights reserved. 


\section{Asset Management}

Transforming asset dependent businesses

Second edition

Chris Lloyd and Michael Corcoran 
Published by ICE Publishing, One Great George Street, Westminster, London SW1P 3AA.

Full details of ICE Publishing representatives and distributors can be found at: www.icebookshop.com/bookshop_contact.asp

Other titles by ICE Publishing:

Whole-Life Value-Based Decision-Making in Asset Management Ajith Parlikad and Rengarajan Srinivasan. ISBN 978-0-7277-6061-6

International Case Studies in Asset Management

Chris Lloyd. ISBN 978-0-7277-5739-5

BIM in Principle and in Practice, Third edition

Peter Barnes. ISBN 978-0-7277-6369-3

www.icebookshop.com

A catalogue record for this book is available from the British Library

ISBN 978-0-7277-6143-9

(c) Thomas Telford Limited 2019

ICE Publishing is a division of Thomas Telford Ltd, a wholly owned subsidiary of the Institution of Civil Engineers (ICE).

All rights, including translation, reserved. Except as permitted by the Copyright, Designs and Patents Act 1988, no part of this publication may be reproduced, stored in a retrieval system or transmitted in any form or by any means, electronic, mechanical, photocopying or otherwise, without the prior written permission of the Publisher, ICE Publishing, One Great George Street, Westminster, London SW1P 3AA.

This book is published on the understanding that the authors are solely responsible for the statements made and opinions expressed in it and that its publication does not necessarily imply that such statements and/or opinions are or reflect the views or opinions of the publisher. While every effort has been made to ensure that the statements made and the opinions expressed in this publication provide a safe and accurate guide, no liability or responsibility can be accepted in this respect by the authors or publisher.

While every reasonable effort has been undertaken by the authors and the publisher to acknowledge copyright on material reproduced, if there has been an oversight please contact the publisher and we will endeavour to correct this upon a reprint.

Cover photo: Travelers on a moving sidewalk in a tunnel at United terminal passing Sky's the Limit (a neon sculpture by artist Michael Hayden) at O'Hare International Airport, Chicago, Illinois USA. Blaine Harrington III/Alamy Stock Photo

Commissioning Editor: Michael Fenton

Production Editor: Madhubanti Bhattacharyya

Marketing Specialist: April Asta Brodie

Typeset by Academic + Technical, Bristol

Index created by Laurence Errington

Printed and bound in Great Britain by Latimer Trend, Plymouth 


\section{Contents}

Foreword

Preface

About the contributors

List of abbreviations

vii

ix

$\mathrm{xi}$

xvii

Introduction. One name for many things

Chris Lloyd

Section 1. The state of the art

01

Asset Management - the first 20 years

Richard Edwards

02

Asset management maturity and the pursuit of value

Martin Pilling

03

Research challenges in Asset Management

Ajith Kumar Parlikad

Section 2. Developing asset management culture and practice

04

Creating an asset management culture

Charles Johnson

05

Building an Asset Management Competence

Framework for your business

Chris Lloyd and Michael Corcoran

06

Realizing the return on investment of

Asset Management

Kimberlee Williams

Section 3. Future directions

07

Incorporating climate change within

Asset Management

Ralph Rayner

08

Infrastructure Asset Management in the age of smart cities

Michael A Salvato

09

Digital Asset Management

Richard Edwards 


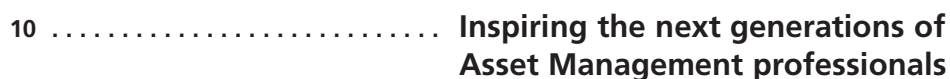

Michael Corcoran

11

Asset Management - technically interesting or business critical?

209

Anthony Vaughan

Chris Lloyd

Index

231

vi

Downloaded by [] on [26/04/23]. Copyright @ ICE Publishing, all rights reserved. 
When the first edition of this book was published in 2010, the world of Asset Management was very different. ISO 55000 was five years away, the current proliferation of software tools and good practice guidance had barely started, organisations embracing asset management thinking and practices were seen as early adopters, and the asset management profession was organised nationally rather than as the global community of practice it is today.

The speed at which Asset Management has moved from the fringe to the mainstream of business practice is not so surprising. Globally, in the last ten years, the surge in demand for transport infrastructure, utility services and housing has been history making. Whether they realise it or not, Asset Management is now a core competence for any business whose success depends on physical assets being available in the right condition at the right price.

Whereas the first edition of this book was about the potential of Asset Management to transform the way asset-dependent businesses are run, this new edition celebrates its achievements and points to its future role in handling the impacts of urbanisation and climate change and in developing the next generation of Asset Management professionals. The principles and information set out in the first edition still apply, but there is more emphasis now on the techniques needed to rise to these challenges. From my perspective, where Asset Management can and should make the biggest difference is by ensuring more responsible, far-sighted use of natural capital principles to preserve natural resources, and by educating policymakers in the realities of delivering reliable infrastructure for essential services. So it pleases me to see the greater emphasis given to combatting climate change in this second edition.

Asset Management professionals are becoming more diverse and demanding, bringing with them a wider 
range of education and experience, career expectations and learning needs. This book is an invaluable source of reference that will be of value to students, people new to Asset Management roles and experienced Asset Management professionals.

Chris Newsome OBE

President, the Institute of Asset Management 
Producing the second edition of this book has not been the walk in the park I thought it would be when the publishers asked me if I would like to do it. For a start, Asset Management and its context have moved on in many ways, so some of the old content needed to make room for some new content that better reflects where it has got to. The emphasis is less theoretical now, more marked by experiences of trying to get executive attention for Asset Management and deliver its promises. The book is also full of warnings - that Asset Management is still in danger of being mistaken for a branch of engineering and that it needs to step up its game if industry is to mitigate or adapt to climate change, to name but two of them.

It took a good while to get all the chapters into a coherent piece because our contributors are busy people, but it was worth the wait and I would like to thank them for articulating and sharing their thoughts and experiences so freely.

This time around, I decided to share the task of putting the book together with my colleague Michael Corcoran, Associate Director of CAS, the London-based company I founded in 1997, which I now chair. Michael has a distinctive take on how Asset Management can be popularised, how it should be taught and where the profession is headed. His opinions may have been shaped by his work with me on the development of the Institute of Asset Management's Professional Development Framework and for various CAS corporate clients, but they are sharpened by his passion for and achievements in engaging people with science and the arts. For this reason, what started as my cunning plan to cut the workload involved in producing this book quickly became an engrossing collaboration and I thank Michael for that.

My thanks also to Chen Chen, Managing Director of CAS, for her encouragement and, yet again, to Carol.

Chris Lloyd 
Downloaded by [] on [26/04/23]. Copyright @ ICE Publishing, all rights reserved. 


\section{About the contributors}

\section{Michael Corcoran}

Michael Corcoran is a consultant and curator, specialising in the design of creative solutions to education, communication and engagement challenges. He is Associate Director at Competence Assurance Solutions Ltd (CAS) and Head of Professional Development for Arete, was Project Manager for the Institute of Asset Management's 2016-2017 Task Force on Professional Development and Qualifications and works with numerous educational and creative organisations in the UK. He has published several papers internationally on themes relating to interdisciplinary and entrepreneurial education. A passionate advocate for public engagement with the arts and sciences, he regularly curates and hosts exhibitions, festivals and events in his native Wales. He holds a degree in physics and philosophy from Durham University, and is an Associate Fellow of the Higher Education Academy.

\section{Richard Edwards}

Richard Edwards MA, MIET, FIAM is a Chartered Engineer who provides strategic advice to a range of global infrastructure owners and regulators on the application and benefits of Asset Management and other business-related issues. After graduating from Oxford University, he worked in the rail industry for 15 years before moving into strategic asset management consultancy. He has been a director of Asset Management Consulting Ltd (AMCL) for 20 years and is currently the Global Technical Director and the technical authority for the development of products and services within AMCL. Richard is the immediate Past President of the Institute of Asset Management (IAM) and continues as a board member and life fellow. He represents the IAM at the Global Forum on Maintenance and Asset Management.

\section{Charles Johnson}

Dr Charles Johnson is an Associate Fellow of the British Psychological Society and a Chartered 
Occupational Psychologist. Over the last 30 years, he has supplied psychological and human factors expertise to the health industry, financial sector, construction and engineering sectors, chemical and pharmacological industry, military, security and emergency services, transport sectors and various government departments. His work has involved him in organisational development and change management, culture change, crisis management and disaster recovery, competence management, market research, assessment and selection, psychological testing, career counselling, job design and ergonomics. Charles is Managing Director of Johnson Doughty Ltd, Technical Director of CAS and Director of Psychological Services for Cambridge Occupational Analysts Ltd. From 2000 to 2004 he was Chair of the British Psychological Society's Steering Group on Test Standards and remains a member of its test review panel.

\section{Chris Lloyd}

Chris Lloyd MA is Chairman of CAS, which helps clients improve the quality and impact of compulsory training and licensing programmes. He also chairs Arete, which delivers educational, training and career opportunities to Chinese graduates, and East Fortune Lifestyles, which develops unique collaborations between contemporary UK artists and brands in China. $\mathrm{He}$ is a co-founder and past director of AMCL, Asset Management Academy and Vertex Systems Engineering. His books on Asset Management are key references for students and professionals and he has written many articles on safety, culture and workforce development. A Member of the Institute of Asset Management, in 2006-2014 he led the development of its Competences Framework and Professional Qualifications and in 2016-2017 he headed its Task Force on Professional Development and Qualifications. Chris is volunteer Chairman of Vic Studios - an award-winning, non-profit music service for young people based in Wrexham, North Wales. 


\begin{abstract}
Ajith Kumar Parlikad
Dr Ajith Kumar Parlikad is Senior Lecturer in Industrial Systems at Cambridge University Engineering Department. He is a co-investigator for the Centre for Smart Infrastructure and Construction and the Centre for Digital Built Britain at Cambridge University. He leads a research team focused on examining how data and digital technologies can be exploited to improve asset investment and maintenance decision making. His research has been funded by the Engineering and Physical Sciences Research Council (EPSRC), Innovate UK, EU Horizons 2020 and industry. Dr Parlikad sits on the steering committee of the International Federation of Automatic Control Working Group on Advanced Maintenance Engineering, Services and Technology and is a member of the Digital Twin Working Group of the UK Digital Framework Task Group. Dr Parlikad's current research focuses on the development of digital twins of complex asset systems, bringing together data from disparate sources to improve infrastructure Asset Management.
\end{abstract}

\title{
Martin Pilling
}

Martin Pilling BEng, CEng, MIET, FIAM is a Chartered Engineer with outstanding experience of Asset Management in the utilities, transportation and infrastructure sectors across Europe, the Middle East, Australasia and North America. He is a founding director of AMCL, where his pragmatic approach has been honed through helping organisations in their journey towards Excellence in Asset Management. He has successfully led multidisciplinary teams in the delivery of complex projects to demanding timescales, including the implementation of integrated Asset Management Systems aligned with ISO 55001 within both highly regulated and commercial environments.

\section{Ralph Rayner}

Professor Ralph Rayner is a Professorial Research Fellow in the Centre for the Analysis of Time Series at the London School of Economics and Political 
Science. He has responsibility for industry outreach for the Integrated Ocean Observing System at the US National Oceanic and Atmospheric Administration and is President of the Society for Underwater Technology. During his career he has been responsible for a number of consultancy companies specialising in the provision of environmental criteria in support of the design and operation of marine and maritime infrastructure. He has authored numerous scientific papers and reports concerned with monitoring, understanding and predicting the ocean environment and is Editor-in-Chief of the Journal of Operational Oceanography.

\section{Michael A Salvato}

Michael A Salvato is Vice President of Advisory Services at Mott MacDonald, a global engineering, management and development consultancy. He works with infrastructure owners and operators to unlock the asset value, efficiencies and sustainability required to meet the rising expectations of customers, governments, industry and society. $\mathrm{He}$ has pioneered the application of digital technologies to Asset Management, urban infrastructure and smart cities and is a thought leader in Urban Systems and Informatics. In 2018, he retired as Director and Programme Executive for Enterprise Information and Asset Management at the New York State Metropolitan Transportation Authority, where he led a transformational programme to improve the safety, reliability, life cycle costs and resiliency of the New York transportation system, which has US \$1 trillion of infrastructure and assets. He was founding Chair and Country Vice President of the Institute of Asset Management in the USA and on the US delegation that worked on ISO 55000 . He is on the board of Smart City New York, Research Professor of Urban Infrastructure Systems at New York University Tandon School of Engineering, where he helped set up the Center for Urban Science and Progress, and an adviser to Blueprint 2025, a National Infrastructure Plan. 
The question driving his work in architecture, engineering, construction, programme management, economic development, information technology and public policy over the last 35 years is how innovation can be applied to create a more sustainable built environment.

\section{Kimberlee Williams}

Kimberlee Williams is President of the Center for Strategy Realization, which provides advisory services, capability building programmes, assessments and a proven approach that equips business leaders to fully realise the results of their highest-value initiatives. Her professional domain is business transformation, where the entire organisation must be mobilised to realise the benefits of a number of concurrent megaprojects. Prior to founding the company, she served as Head of Global Change Execution at Merck \& Co. during the most transformational period in the company's history. She has also held senior organisation and operational effectiveness roles in firms, where she served Fortune 100 companies across 18 industries on projects that spanned every aspect of the enterprise value chain. She holds a BA in industrial and organisational psychology, an MA in social relations and research methods, and is a certified Master Change Agent and Lean Sigma Black Belt. She resides on the beautiful Hudson River waterfront in Jersey City, New Jersey, USA.

\section{Anthony Vaughan}

Dr Anthony Vaughan is Senior Vice President of Infrastructure for Brookfield Asset Management, a leading global alternative asset manager and one of the largest private sector infrastructure investors in the world. Brookfield owns and operates utilities, transport, energy, data infrastructure and sustainable resources assets - delivering essential goods and services across toll roads, rail networks, ports and pipelines. Dr Vaughan provides technical due diligence and operational asset management leadership for the company, and holds a number of board positions. Prior to Brookfield, Dr Vaughan 
worked in senior engineering Asset Management roles in energy infrastructure, and operational roles in open-cut and underground mining. Dr Vaughan holds a BEng (Mech), a master's degree in maintenance management and a $\mathrm{PhD}$, for which he investigated the leadership skills required by executives to manage infrastructure assets. He is a Certified Professional Engineer with the Institute of Engineers, Australia, and a member of the Institute of Asset Management (UK), the Asset Management Council (Australia) and the Australian Institute of Company Directors. 


\section{Abbreviations}

\begin{tabular}{|c|c|}
\hline $\begin{array}{l}\text { ALARP } \\
\text { AMCF }\end{array}$ & $\begin{array}{l}\text { as low as reasonably practical } \\
\text { Asset Management Competence } \\
\text { Framework }\end{array}$ \\
\hline AMCL & Asset Management Consulting Ltd \\
\hline AMEM & Asset Management Excellence Model \\
\hline AMP & Asset Management Plan \\
\hline ARM & Asset Risk Management \\
\hline ASSE & American Society of Safety Engineers \\
\hline BIM & building information modelling \\
\hline $\begin{array}{l}\text { BSI } \\
\text { capex }\end{array}$ & $\begin{array}{l}\text { British Standards Institute } \\
\text { capital expenditure }\end{array}$ \\
\hline CAS & Competence Assurance Solutions \\
\hline CMMS & $\begin{array}{l}\text { computerised maintenance } \\
\text { management systems }\end{array}$ \\
\hline EAM & enterprise asset management \\
\hline EAMS & enterprise asset management system \\
\hline EPSRC & $\begin{array}{l}\text { Engineering and Physical Sciences } \\
\text { Research Council }\end{array}$ \\
\hline ESE & Enterprise Systems Engineering \\
\hline ET & engineering technologies \\
\hline FTA & Federal Transit Administration \\
\hline GFMAM & $\begin{array}{l}\text { Global Forum on Maintenance and } \\
\text { Asset Management }\end{array}$ \\
\hline HKM & Hitchins-Kasser-Massie \\
\hline HSE & Health and Safety Executive \\
\hline IAM & Institute of Asset Management \\
\hline ICE & Institution of Civil Engineers \\
\hline IEC & $\begin{array}{l}\text { International Electrotechnical } \\
\text { Commission }\end{array}$ \\
\hline IEEE & $\begin{array}{l}\text { Institute of Electrical and Electronics } \\
\text { Engineers }\end{array}$ \\
\hline IoT & Internet of Things \\
\hline IPCC & $\begin{array}{l}\text { Intergovernmental Panel on Climate } \\
\text { Change }\end{array}$ \\
\hline ISO & $\begin{array}{l}\text { International Organization for } \\
\text { Standardization }\end{array}$ \\
\hline & information technologies \\
\hline
\end{tabular}




\begin{tabular}{|c|c|}
\hline ITU & $\begin{array}{l}\text { International Telecommunication } \\
\text { Union }\end{array}$ \\
\hline LIDAR & light detection and ranging \\
\hline MAP-21 & $\begin{array}{l}\text { Moving Ahead for Progress in the } \\
\text { 21st Century Act }\end{array}$ \\
\hline MRM & Maintenance Resource Management \\
\hline NIST & $\begin{array}{l}\text { National Institute of Standards and } \\
\text { Technology }\end{array}$ \\
\hline Ofgem & Office of Gas and Electricity Markets \\
\hline OHS & occupational health and safety \\
\hline OIR & $\begin{array}{l}\text { organisational information } \\
\text { requirements }\end{array}$ \\
\hline opex & operational expenditure \\
\hline ORR & Office of Rail Regulation \\
\hline OT & operational technologies \\
\hline PDKM & $\begin{array}{l}\text { product data and knowledge } \\
\text { management }\end{array}$ \\
\hline PFI & private finance initiative \\
\hline PMO & project management office \\
\hline PPP & public-private partnership \\
\hline PSS & product-service systems \\
\hline $\mathrm{RCM}$ & reliability centred maintenance \\
\hline $\mathrm{RCP}$ & representative concentration pathway \\
\hline RISE & $\begin{array}{l}\text { Research and Innovation Staff } \\
\text { Exchange }\end{array}$ \\
\hline ROI & return on investment \\
\hline SAMP & Strategic Asset Management Plan \\
\hline SBP & strategic business plan \\
\hline SE & systems engineering \\
\hline SH\&E & safety, health and environmental \\
\hline SICT & $\begin{array}{l}\text { sensing, information and } \\
\text { communication technologies }\end{array}$ \\
\hline TOGAF & The Open Group Architectural Foru \\
\hline UKCIP & UK Climate Projections \\
\hline
\end{tabular}

